原著

ナトリウム利尿ペプチドファミリーのラット内耳での局在

鈴木 幹男·北西 剛・北野 博也

矢澤代四郎・北嶋 和智

\title{
Immunoreactivity of the Atrial Natriuretic Peptide Family in the Rat Inner Ear
}

\author{
Mikio Suzuki, Tsuyoshi Kitanishi, Hiroya Kitano, \\ Yoshiro Yazawa, Kazutomo Kitajima \\ Department of Otolaryngology, Shiga University of Medical Science
}

The atrial natriuretic peptide family (ANP family) is comprised of atrial natriuretic peptide (ANP), brain natriuretic peptide (BNP) and C-type natriuretic peptide (CNP). These peptides regulate body fluid and blood pressure homeostasis as a neuropeptide in the central nervous system as well as a cardiac hormone in the periphery. To assess the possible physiological role of the ANP family, we investigated the immunohistochemical localization of these peptides in the rat inner ear. ANP-like and CNP-like immunoreactivities were observed in the spiral ligament just beneath the stria vascularis, spiral limbus, dark cell area, endolymphatic sac, spiral ganglion cells and vestibular ganglion cells. We could not detect specific BNP-like immunoreactivity in the inner ear. These observations were consistent with our previous study concerning the ANP family gene expression. The results suggest that the ANP family influences the metabolism of the inner ear fluid as well as afferent nerve activities in the inner ear.

Key words: ANP family, inner ear, immunohistochemistry, endolymph, perilymph, afferent nerve

\section{はじめに}

メニエール病は特発性内リンパホ腫を病理とす る疾患であるが，内リンパ水腫形成の機序は未だ 不明である。我々は内リンパ水腫形成要因とし て, ウイルス等による側頭骨の発育障害1) 3), 自 己免疫異常4)5)，内耳液代謝異常6) 8) を想定し， 基礎的, 及び臨床的研究を続けている。近年, 内 耳液代謝のホルモン調節に関して,メニエール病

滋賀医科大学耳鼻咽搌科学教室 新專門会員
患者で血清抗利尿ホルモン (以下, $\mathrm{ADH}$ と略す) が高值であること9)10), ADH リセプター阻害剤 がメニエール病に有効であること11), 内耳任変化 が ADH の分泌を調節している可能性が相次いで 報告12)された。我々もラット内耳に $\mathrm{ADH} の \mathrm{~V} 2$ receptor の遺伝子発現があり, $\mathrm{ADH}$ が内耳液代 謝に関与している可能性を報告している7)。ナト りウム利尿ペプチドファミリーは ANP (Atrial natriuretic peptide), BNP (Brain natriuretic peptide), CNP (C-type natriuretic peptide) の 3 種類のペプチドで構成され，主たる機能は生体に 
扣ける水，電解質代謝の調節と考えられている が，多様な組織で分泌され機能調節を司っている ことがわかってきた13114)。ANP，BNP は主な産 生部位はそれぞれ心房筋, 心室筋で, 血管拡張, ナトリウム利尿を促進する。一方，CNP は全身 作用は前 2 者よりる軽微であるが，水電解質代謝 や血管拡張，血管内皮増殖別制などに働くと報告 15) 17) されている。さらに中枢神経系でもナトり ウム利尿ペプチドフォミリーが産生されることが 確認されて和り，ニューロペプチドとして神経伀 達, 神経内分泌の調節, 脳脊咀液産生の調節, グ リア細胞の増殖抑制, 神経ーグリア間の水電解質 代謝などに関与していると報告13)されている。 また，中枢神経系でのナトリウム利尿ペプチドフ アミリーは視床下部ではレニンーアンギオテンシ ン系と拮抗し， $\mathrm{ADH}$ 分泌の抑制，プロラクチン 分泌抑制を介して, 中权性に水電解質代謝を行っ ている。我ふはナトリウム利尿ペプチドフっミ リーがレニンーアンギオテンシン系に拮抗するこ とに着目し, 内耳でも同様の拮抗作用が存在し, 水電解質代謝に関与している可能性があると考 え, RT-PCR を用いて, ラット内耳での遺层子 発現を検討した ${ }^{8)}$ 。この結果, 内耳でのANP, CNP 産生, 3 種類のナトリウム利尿ペプチドフ ア ミリーのリセプター（ANP-A（GC-A: ANP，BNP との結合能が高い), ANP-B (GC-B: CNP との 結合能が高い), ANP-C (ANP, BNP, CNP の クリアランスリセプター）の存在が示唆された。

本論文ではこれら 3 種類のナトリウム利尿ペプ チドファミリーが内耳のどの部位に存在するかを 検討することにより，ナトリウム利尿ペプチドフ ァミリーが内耳でどのように作用しているかを推 察することにある。この目的のために，ANP， BNP, CNP に対する抗体を用い免疫組織化学の 手法を用いて，ラット内耳での各ペプチドの局在 を検討したので報告する。

\section{方法及び結果}

体重約 $200 \mathrm{~g}$ の Wister ラット20匹を用いた。 $0.01 \mathrm{M}$ リン酸緩衝食塩水 (以下, PBS と略す) にて灌流脱血の後, 固定液 $200 \mathrm{ml}(0.1 \mathrm{M}$ リン 酸楥衝液 (以下, PB と略す)，4\%ハラフォルム アルデヒド, $0.2 \%$ ピクリン酸, $0.35 \%$ グルタル アルデヒド）にて灌流固定した。内耳を側頭骨と 一体にして取り出し，中耳骨胞を除去し，上記の
固定液からグルタルアルデヒドを除いた固定液中 で24時間 $4^{\circ} \mathrm{C}$ で後固定した。15\%シュクロース 加 0.1 MPB で洗浄したのち， $4 \%$ EDTA 加 0.1 MPB 中で脱灭を約 2 週間行った。脱灰後， $10 \%$ ゼラチン加 0.1 MPBに包埋した。4\%パラフォ ルムアルデヒドにてゼラチンを固定後, $15 \%$ ン クロース加 0.1 MPB で洗浄した。標本を炭酸が スにて凍結し，凍結標本をクライオスタットで $20 \mu \mathrm{m}$ の厚さに薄切した。薄切切片は浮遊法にて 下記の反応を行った。むず， $0.3 \% \mathrm{H}_{2} \mathrm{O}_{2}$ で内因 性ペルオキシダーゼを不活化した。10\%正常ブタ 血清で非特異的反応をブロッキングのあと, 1 次 抗体（1\%ウシ血清アルブミンを含んだ $0.03 \%$ 卜 リトン加 $0.1 \mathrm{M}$ PBS (以下, PBST と略寸) 飞 て5000倍に希釈) 中に $4^{\circ} \mathrm{C} 48$ 時間インキュベー トした。PBST にて洗浄啳, 再び，10\%正常ヤ ギ血清で非特異的反応をブロックした。この後, 2 次抗体（ビオチン標識ヤギ抗ウサギ Ig G 抗 体, Vectastain Co., USA, PBST にて500倍に希 釈）に室温で 1 時間インキュベートした。PBST 洗浄後, ABC 溶夜 (Vectastain Co., ABC-Elite, USA, PBST にて 4000 倍希釈) 中で 1 時間インキ ュベートした。PBSTにて洗浄後, DAB-Ni(0.02 $\% 3,3$ 3゙ァミノベンチジン $-4 \mathrm{HCl}, 0.07 \%$ 塩化 ニッケル6水和物，0.005\%過酸化水素水，0.05 $\mathrm{M} ト$ リス塩酸緩衝液， $\mathrm{pH} 7.6$ ）で10分間発色さ せた。な扣，1次抗体は鬼抗ラット alpha-ANP 抗体，鬼抗 $ッ$ ○ BNP-45 抗体，鬼抗ラット CNP-22 抗体 (Peninsula Lab, England) を用い た。免疫反応の特異性は，1次抗体の代わりに， それぞれ ANP, BNP, CNP (ペプチド研究所, 日本） $4 \mu \mathrm{g} / \mathrm{ml}$ 中にそれぞれの抗体を5000倍希 秎し， $4^{\circ} \mathrm{C} 24$ 時間反応させた抗体吸收液を用い て確認した。

\section{結 果（図 $1 \sim 5$, 表 1 )}

表 1 火免疫染色結果を要とめた。抗体吸収液を 用いた染色で，染色反応が吸収されたものを陽性 所見とし，吸収されなかった部位は非特異的反応 と判定した。

\section{ANPについて}

蝸牛ではラセン神経節，ラセン勒帯，ラセン板 縁が染色された。ラセン勒帯は做漫性に染色さ れ，また，ラセン勒帯・血管条の移行部がより強 く染色された。抗体吸収液を用いた染色では，ラ 

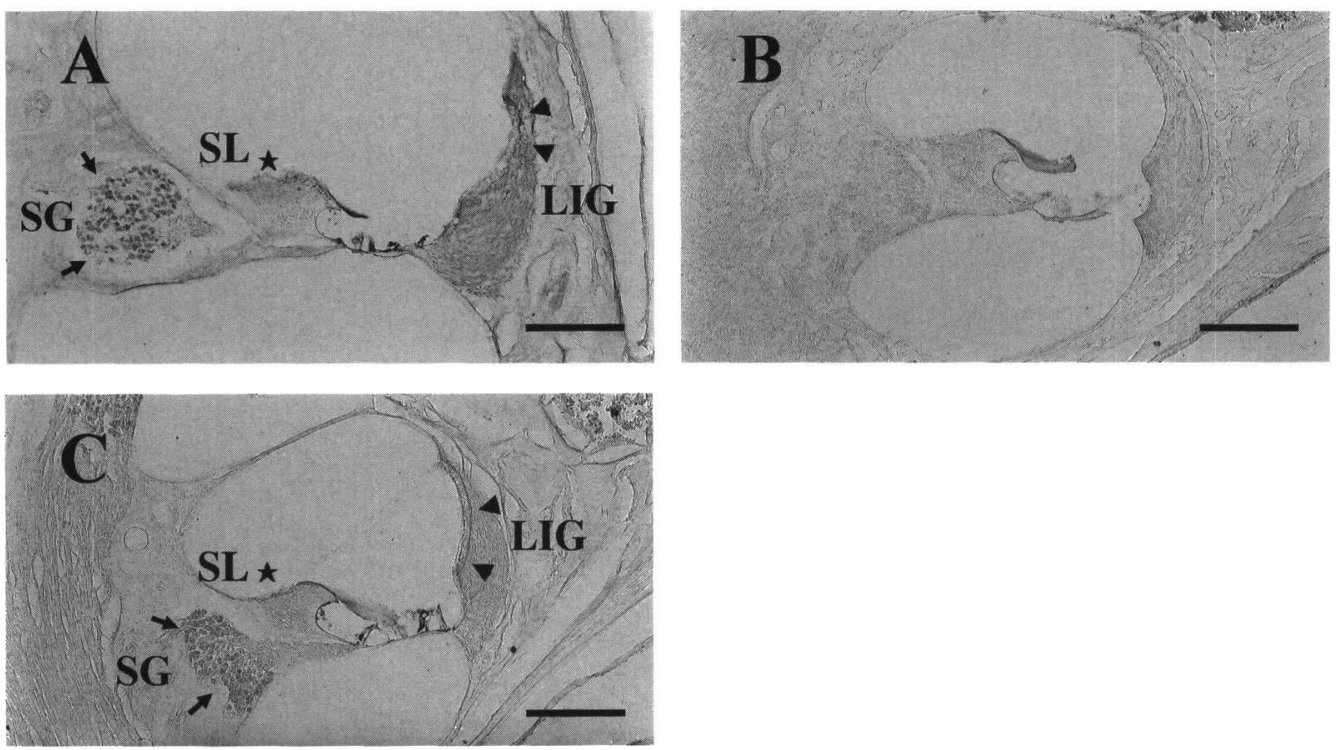

図 1 蝸牛でのナトリウム利尿ペプチドファミリーの局在

いずれる横線は $200 \mu \mathrm{m}$ を示す。

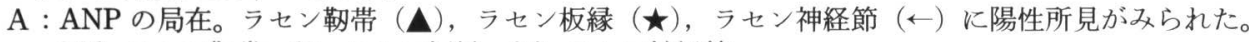
LIG: ラセン勒带, SL: ラセン板縁, SG: ラセン神経節。

B : BNP の局在。蝸牛内に陽性所見を認めなかった。

C : CNP の局在。ラセン勒帯 $(\boldsymbol{\Delta})$ ，ラセン板縁（†），ラセン神経節（Ł）に陽性所見がみられた。 LIG: ラセン勒帯, SL: ラセン板縁, SG: ラセン神経節。
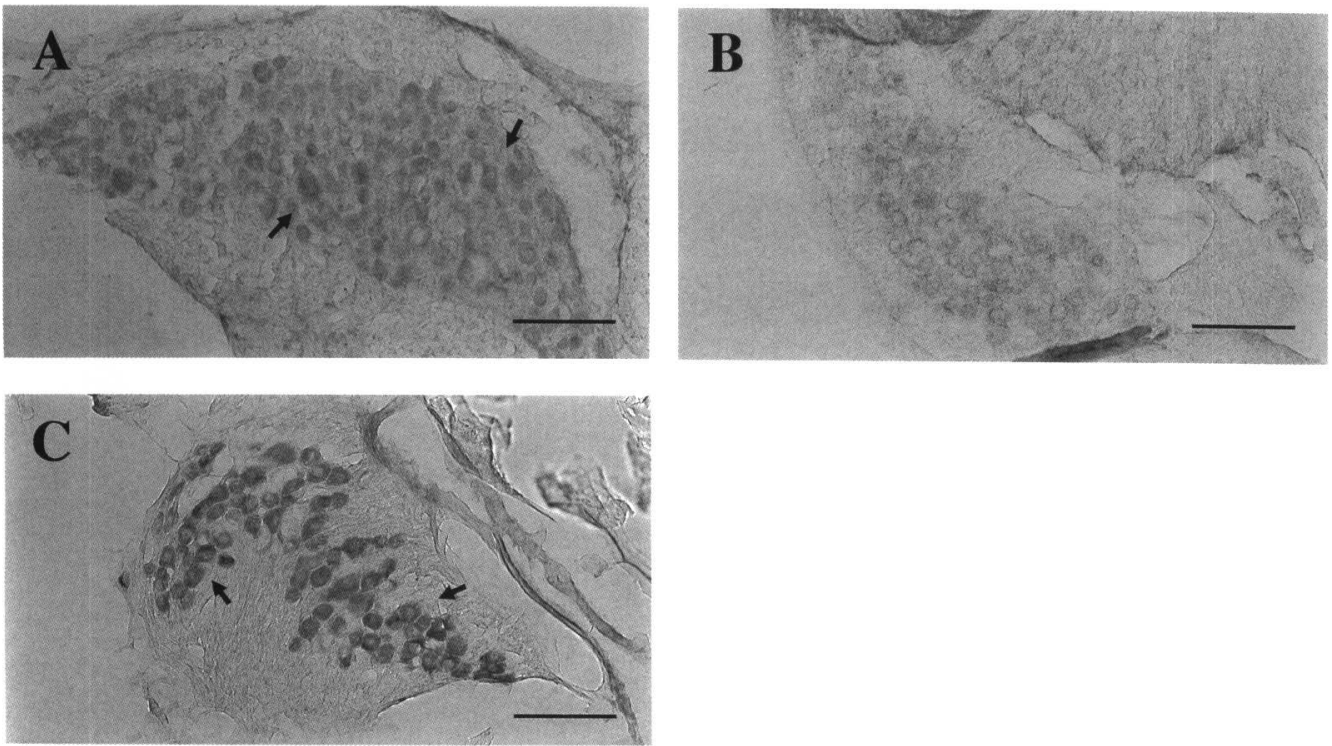

図 2 前庭神経節でのナトリウム利尿ペプチドファミリーの局在 いずれも横線は $100 \mu \mathrm{m}$ を示す。

A : ANP の局在。前庭神経節細胞（ヶ）に陽性所見がみられた。

B : BNP の局在。前庭神経節内に陽性所見を認めなかった。

C : CNP の局在。前庭神経節細胞（Ł）に陽性所見がみられた。 

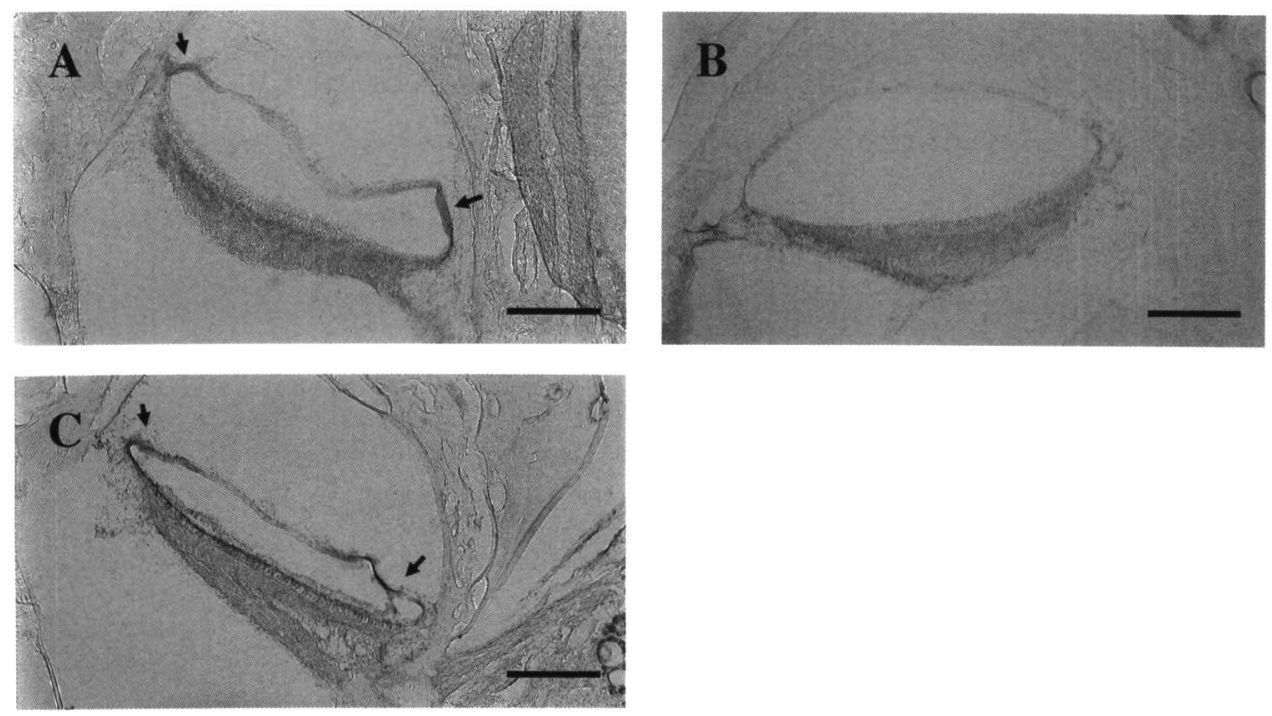

図 3 前庭 (卵形囊) でのナトリウム利尿ペプチドファミリーの局在 いずれも横線は $200 \mu \mathrm{m}$ を示す。

A : ANP の局在。暗細胞部 (ヒ) 飞弱い陽性所見がみられた。感覚上皮下の染色像は抗体吸収液を用い た染色でも吸収されなかった。

B : BNP の局在。前庭内に陽性所見を認めなかった。

C : CNP の局在。暗細胞部 $(\leftarrow)$ 飞弱い陽性所見がみられた。感覚上皮下の染色像は抗体吸収液を用い た染色でも吸収されなかった。
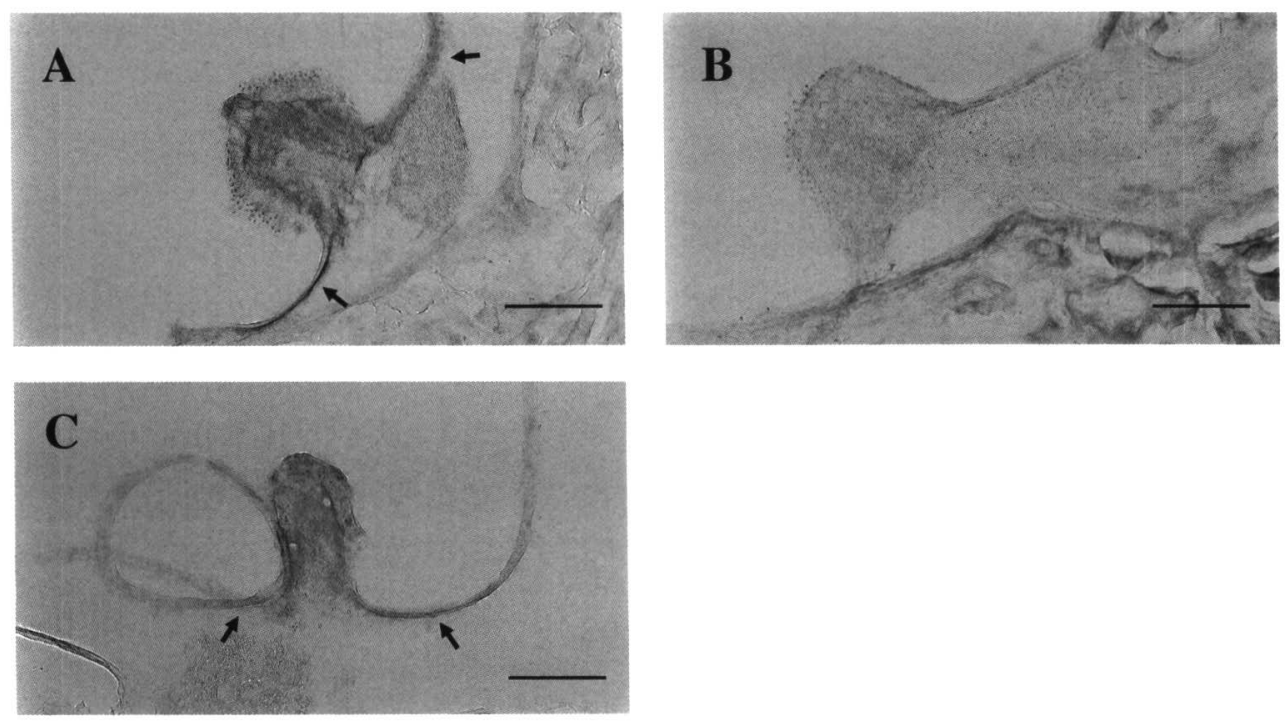

図 4 半規管でのナトリウム利尿ペプチドファミリーの局在

いずれも横線は $200 \mu \mathrm{m}$ を示す。

A : ANP の局在。暗練胞部 (ヒ) 飞弱い陽性所見がみられた。感覚上皮下の染色像は抗体吸收液を用い た染色でも吸収されなかった。

B : BNP の局在。半規管に陽性所見を認めなかった。

C : CNP の局在。暗細胞部 (た) 飞弱い陽性所見がみられた。感覚上皮下の染色像は抗体吸収液を用い た染色でも吸収されなかった。 

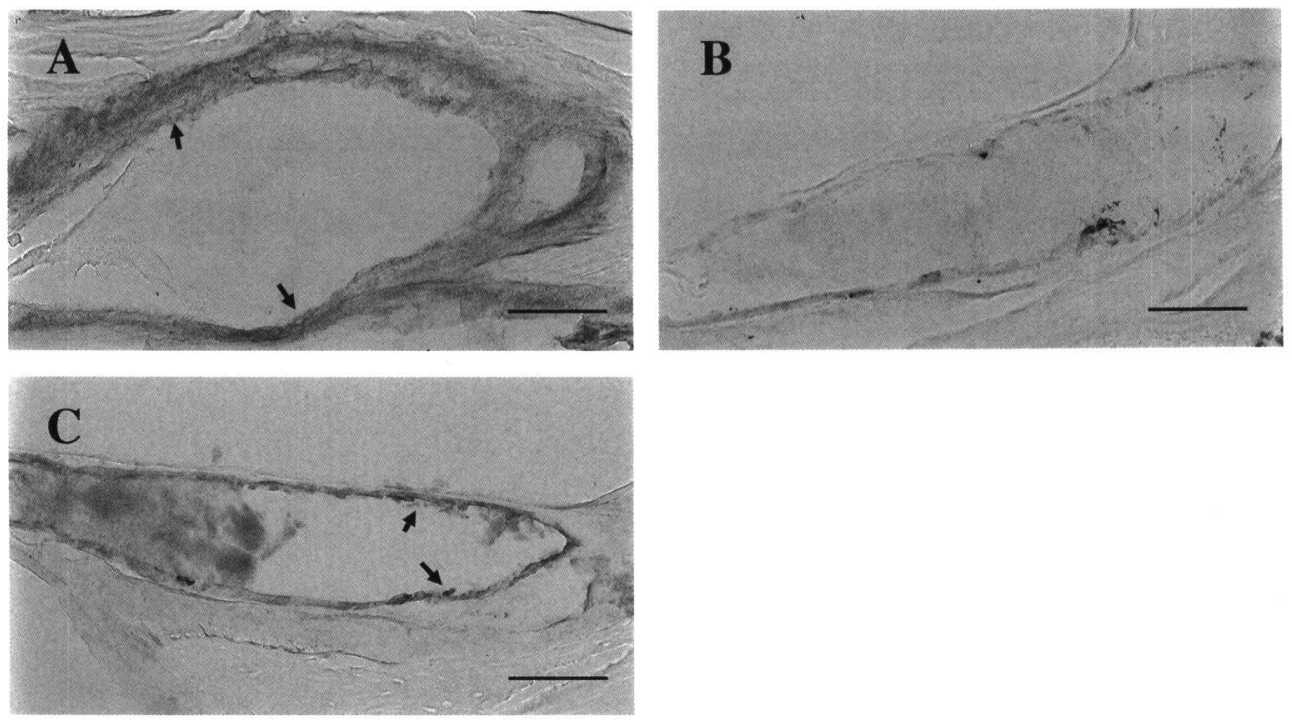

図 5 内リンパ裹でのナトリウム利尿ペプチドフォミリーの局在 いずれも横線は $200 \mu \mathrm{m}$ を示す。

A : ANP の局在。内リンパ囊上皮（Ł）に弱い陽性所見を認めた。

B : BNP の局在。内リンパ囊に陽性所見を認めなかった。

C : CNP の局在。内リンパ裹上皮（〔）に弱い陽性所見を認めた。

表 1 ANP Family の内耳での局在

\begin{tabular}{|c|c|c|c|}
\hline & ANP & BNP & CNP \\
\hline $\begin{array}{l}\text { 蝸牛 } \\
\text { ラセン神経節 } \\
\text { ラセン勒帯 } \\
\text { ラセン板緑 } \\
\text { コルチ器 } \\
\end{array}$ & $\begin{array}{l}(+) \\
(+) \\
(+) \\
(-)\end{array}$ & $\begin{array}{l}(-) \\
(-) \\
(-) \\
(-)\end{array}$ & $\begin{array}{l}(+) \\
(+) \\
(+) \\
(-)\end{array}$ \\
\hline $\begin{array}{l}\text { 前庭 } \\
\quad \text { 前庭神経節細胞 } \\
\text { 暗細胞部 } \\
\text { 感覚上皮 } \\
\text { 上皮下組樴 } \\
\end{array}$ & $\begin{array}{l}(+) \\
(+) \\
(-) \\
(-)\end{array}$ & $\begin{array}{l}(-) \\
(-) \\
(-) \\
(-)\end{array}$ & $\begin{array}{l}(+) \\
(+) \\
(-) \\
(-)\end{array}$ \\
\hline 内リンパ亶上皮 & $(+)$ & $(-)$ & $(+)$ \\
\hline
\end{tabular}

セン勒帯の鿞漫性染色は減弱しなかったが，血管 条直下のラセン勒帯の染色所見は吸収された。ラ セン神経節では細胞質に陽性所見がみられたが, 神経節細胞の軸策には陽性所見はみられなかっ た。ラセン板縁では線維細胞に嘸漫性に弱い陽性 所見を認めた。コルチ器は外有毛細胞周囲が染色 されたが，抗体吸收液で染色しても染色反応は消 失せず，非特異的反応と判定した。

前庭では, 半規管, 球形囊, 卵形囊の上皮下が 籋漫性に染色されたが，抗体吸収液を用いた染色
でも同様に染色され非特異的反応と判定した。前 庭神経節細胞はラセン神経節と同様に細胞質に陽 性所見を認めた。また暗細胞部, 内リンパ囊上皮 は弱い陽性所見を示した。

\section{BNPについて}

蝸牛ではラセン勒帯, 前庭では半規管, 球形 囊, 卵形囊の上皮下が瀰漫性に弱く染色された が，抗体吸収液を用いた染色では，この所見は消 失せず, 非特異的反応と判定した。ラセン神経 節, 前庭神経節, 内リンパ嚢上皮, 暗細胞部に陽 性所見を認めなかった。

$$
\text { 3. CNP について }
$$

CNP は, ANP と同様の部位に陽性所見を認め

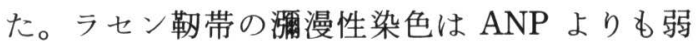
く，抗体吸收液を用いた染色でも消失しなかっ た。ANP と同様に血管条直下のラセン勒帯が陽 性所見を示した。前庭では, 半規管, 球形囊, 卵 形囊の上皮下が弱く籋漫性に染色されたが, 抗体 吸収液を用いた染色でも同様に染色され非特異的 反応と判定した。

\section{考察}

1988年 Lamprecht ら ${ }^{18)}$ は内耳に ANP の受容 
表 2 内耳での ANP 局在に関する報告

\begin{tabular}{|c|c|c|c|}
\hline & $\begin{array}{l}\text { Meyer zum Gottesberge, et al } \\
(1991,1995)\end{array}$ & Yoon, et al $(1992,1994)$ & 本研究(1998) \\
\hline 動物種 & モルモット & S-D ラット & Wister ラット \\
\hline 1 次抗体 & ウサギ抗ヒト $\alpha$-ANP & ウサギ抗ラット $\alpha$-ANP & ウサギ抗ラット $\alpha$-ANP \\
\hline 陽性部位 & & & \\
\hline $\begin{array}{l}\text { 蚂牛 } \\
\text { ラセン䩗帯 } \\
\text { 血管柔 } \\
\text { コルチ器 } \\
\text { ラセン神経節 }\end{array}$ & $\begin{array}{l}(+) \\
(+) \\
(t) \\
(t)\end{array}$ & $\begin{array}{l}(+) \\
(+) \\
(+) \\
(+)\end{array}$ & $\begin{array}{l}(+) \\
(+) \\
(+) \\
(+)\end{array}$ : 吸収されず \\
\hline $\begin{array}{l}\text { 前庭 } \\
\text { 分泌部 (暗細胞部) } \\
\text { 感覚上皮 }\end{array}$ & $\begin{array}{l}(-) \\
(+): \text { 神経杯, 部分的 } \\
\text { 巨吸収 }(+)\end{array}$ & 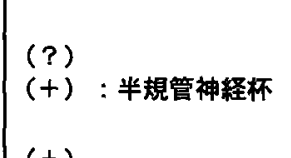 & 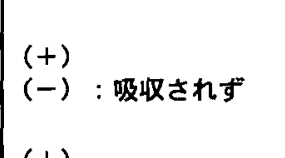 \\
\hline
\end{tabular}

体が存在することをオートラジオグラフィーを用 いて初めて報告した。彼らは，ANP 結合部位 が，蝸牛外側壁（血管条，ラセン勒帯）, 蝸牛軸, 前庭の分泌上皮にあると報告した。さらに，急疫 染色を用いて，ANP が内耳儿存在することが報 告19) 22)され，ANPがオートクリンもしくはパ ラクリンの形をとり，内耳で作用する可能性が提 示された。表 2 に内耳に打居 ANP 存在部位の 報告をまとめた。報告者尤り，動物種，使用抗 体がそれぞれ異なっているが，ラセン勒帯，ラセ ン神経節，内リンパ褧ではいずれも陽性所見を報 告している。ラセン勒帯, 内リン八萑とも内外り ンパ液の産生，吸収に関与する部位であるから， ANP が内耳液代謝に関与する可能性が高いこと を今回の研究でも確認できた。本研究ではラセン 勒帯・血管条の移行部に陽性所見を認めたが，こ の部で ANP が産生されているとすると，血管条 の血管拡張，イオン透過性に影響を与克，内リン パ液の産生以る関与する可能性子考支られる。 た，抗 ANP 抗体，抗 CNP 抗体を用いた免疫染 色では， ラセン神経節，前庭神経節で神経節細胞 が強く染色された。このことは神経ペプチドとし て, 聴覚, 平衡覚の神経伝達に, ナ卜リウム利尿 ペプチドファミリーが関与している可能性を示唆 する。しかし，聴覚，平衡覚の伝垟にどのような
影響を及ぼすのか恃不明であり，今後の検討課題 と思われる。

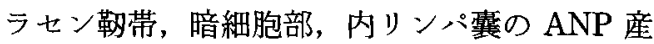
生細胞は血管と直接に接して扣らず，分泌された ANP は拡散によりオートクラインやパラクライ ソの形をとり近傍の細胞に働いていると思われ る。これまでANP の結合部位，リセプターの局 在に関しては，上述のよ5に Lamprecht ら ${ }^{18)}$ 蝸牛外側壁 (血管条, ラセン勒帯), 蝸牛軸, 前 庭の分泌上皮にあると報告しているが，その後， Koch ら ${ }^{23)}$ はオートラジオグラフィーを用いて， 血管条に ANP 結合部位を検出している。彼らは 更に，ANP 投与により血管条での cGMP 産生 を証明して括り，ANP の受容体が血管条にあ り，かつ，ANP が作用していることを強く示唆 している。また Meyer zum Gottesberge ら22) は オートラジオグラフィーを用いて, 蝸牛外側壁, 血管条と卵形賈，半規管膨大部の暗細胞部に結合 部位があることを報告している。いずれも内耳液 の産生部位にリセプターがあることを示して抒 り，ANP が内耳液代謝に関係する可能性を示 し，今回の免疫染色の結果とも一致する。Furuta 5 24) は，RT-PCR を用い，ラセン勒带とラセ ン神経節で ANP-A 受容体（GC-A）の遺伝子発 現を検出したが，血管条では検出できなかったと 
報告した。さらに, in situ hybridization 法では， 蝸牛神経の Oligodendrocyte $に$ ANP-A 受容体の 遺伝子発現を検出できたが，内耳内には検出でき なかったと報告している。我タ6)，Krause ら25) もRT-PCR を用いて ANP-A 受容体の遺伝子発 現が内耳にあることを確認し報告している。これ までの報告から ANP 受容体が内耳に存在するこ とは，ほぼ確実と思われるが，これまでのオート ラジオグラフィーを用いた研究結果と Furuta ら の結果は大きく異なって拉り，ANP-A 受容体の 局在についてはさらに検討が必要と思われる。

我々が文献を弾歩し充た範囲では，BNP， CNP に関して，その局在を検討した報告はこれ までなく，本論文が最初と思われる。BNP は我 我の RT-PCR を用いた検討と一致して内耳に反 応を認めず，内耳で産生されている可能性は低い と思われる。BNPは、ラットでは脳幹部を除く 中权神経系には存在しないとされて拉り，内耳で も同様と思われる。しかし，BNP の受容体であ るANP-A 受容体の遺伝子発現が内耳で報告され ていることから，循環ホルモンとして内耳で作用 する可能性は否定できない。CNP の免疫染色で 陽性部位は, ANP とほぼ一致した。抗 ANP 抗 体, 抗 CNP 抗体の特異性が問題となるが，それ ぞれの抗原で吸収すると免疫反応が消失するた め，CNP の陽性所見は抗体の交差反応ではなく， 両者が同じるしくは近接する細胞に存在するため と推察される。

臨床的には Lamprecht $5^{26)}$ は, メニエール病 患者のグリセロールテスト中, 血中の ANP, cGMP が増加することを報告し，グリセロールテストで の聴力改善が ANP 增加により生じているのでは ないかと推論している。また児玉27) は聴力が変 動するメニエール病例では ANP が有意に低值を 示すことを報告している。これらの報告は，ヒト においてナトリウム利尿ペプチドファミリーが内 耳に作用を及ぼし, 内耳機能を調節している可能 性を示するのである。ラットを用いた我々の基礎 的研究では，ANP，CNP は内耳内で産生され， 内耳内で作用し，BNP は循環ホルモンとして内 耳で作用している可能性を示した。これまで報告 されている臨床観察, 生理実験との間を詰めて行 くことにより，ナトリウム利尿ペプチドファミ リーが内耳で果たす役割やメニエール病をはじめ
とする内耳疾患への臨床応用について明らかにで きると考える。

本研究の一部は文部省科学研究費補助金 $(\mathrm{N}$ 008671961）により行われた。

文 献

1) Yazawa Y, Kitahara M: Computerized tomography of the petrous bone in Meniere's disease. Acta Otolaryngol Suppl (Stockh) 510: 67-72, 1994

2 ) Yazawa Y, Kitahara M: Computerized tomographic findings in endolymphatic sac surgery in Meniere's disease. Acta Otolaryngol Suppl (Stockh) 510: 73-76, 1994

3 ）矢澤代四郎, 鈴木幹男, 田中 寛, 他 : 一側 xニェール病の患側判定に括ける内耳 CT 画像所見の役割. Equilibrium Res 55: 552555,1996

4) Suzuki M, Kitahara M: Immunologic abnormality in Meniere's disease. Otolaryngol Head Neck Surg 107: 57-62, 1992

5) Suzuki M, Krug MS, Cheng KC, et al: Antibodies against inner ear proteins in the sera of patients with inner ear diseases. ORL 59: 10-17, 1997

6) Suzuki M, Kitano H, Kitanishi T, et al: Detection of C-type natriuretic peptide (CNP) and atrial natriuretic peptide (ANP-B) receptor mRNAs in rat inner ear. Neuroreport 8: 439-443, 1997

7 ) Kitano H, Takeda T, Suzuki M, et al: Vasopressin and oxytocin receptor mRNAs are expressed in the rat inner ear. Neuroreport 8: 2289-2292, 1997

8) Suzuki M, Kitano H, Kitanishi T, et al: RTPCR analysis of mRNA expression of natriuretic peptide family and their receptors in rat inner ear. Mol Brain Res 55: 165-168, 1998

9) 石井正則, 白沢昭弘, 八代利伸, 他: ェール病とADH について. Equilibrium Res 50: 62, 1991

10) Takeda $T$, Kakigi A, Saito $H$ : Antidiuretic hormone $(\mathrm{ADH})$ and endolymphatic hy- 
drops. Acta Otolaryngol Suppl (Stockh) 519 : 219-222, 1995

11) 石井正則, 吉田茂, 八代利伸, 他: 入二 エール病に対する抗バゾップレシン作動薬の 効果. Equilibrium Res 56: 124, 1997

12) Bartoli E, Satta A, Melis F, et al: Volume receptors in guinea pig labyrinth: relavance with respect to $\mathrm{ADH}$ and $\mathrm{Na}$ control. Am J Physiol 253 (3 Pt 2) : F341-346, 1989

13) Imura $H$, Nakao $K$, Itoh $H$ : The natriuretic peptide system in the brain: implications in the central control of cardiovascular and neuroendocrine functions. Front Neuroendocrinology 13: 217-249, 1992

14) Gerbes AL, Dagnino L, Nguyen $T$, et al: Transcription of brain natriuretic peptide and atrial natriuretic peptide genes in human tissues. J Clin Endocrinol Metab 78: 13071311,1994

15) Shirakami G, Itoh $H$, Suga $S$, et al: Central action of $\mathrm{C}$-type natriuretic peptide on vasopressin secretion in consciou rats. Neurosci Lett 159: 25-28, 1993

16) Cargill RI, Struthers AD, Lipworth $\mathrm{BJ}$ : $\mathrm{Hu}-$ man $\mathrm{C}$-type natriuretic peptide: effects on the haemodynamic and endocrine response to angiotensin II. Cardiovasc Res 29: 108-111, 1995

17) Naruko $T$, Ueda $M$, van der Wal $A C$, et al: C-type natriuretic peptide in human coronary atherosclerotic lesions. Circulation 94: 31033108,1996

18) Lamprecht J, Meyer zum Gottesberge AM: The presence and localization of receptors for atrial natriuretic peptide in the inner ear of the guinea pig. Arch Otorhinolaryngol 245: 300-301, 1988

19) Meyer zum Gottesberge AM, Gagelmann $M$, Gorssmann WG: Atrial natriuretic peptidelike immunoreactive cells in the guinea pig inner ear. Hear Res 56: 86-92, 1991

20) Yoon YJ, Hellstrom S: Immunohistochemical localization of a-atrial natriuretic polypeptide in the rat cochlea. Acta Otolaryngol (Stockh) 112: 604-610, 1992

21) Yoon YJ, Anniko M: Distribution of alphaANP in the cochlea and the vestibular organs. ORL 56: 73-77, 1994

22) Meyer zum Gottesberge AM, Schleicher A, Drummer C, et al: The volume protective natriuretic peptide system in the inner ear. Acta Otolaryngol Suppl (Stockh) 520: 170173, 1995

23) Koch T, Gloddek B, Gutzke S: Binding sites of atrial natriuretic peptide (ANP) in the mammalian cochlea and stimulation of cyclic GMP synthesis. Hear Res 63: 197-202, 1992

24) Furuta H, Mori N, Luo L, et al: Detection of mRNA encoding guanylate cyclase $\mathrm{A} /$ atrial natriuretic peptide receptor in the rat cochlea by competitive polymerase chain reaction and in situ hybridization. Hear Res 92: 7884, 1995

25) Krause G, Meyer zum Gottesberge AM, Wolfram G, et al: Transcripts encoding three type of guanylyl-cyclase-coupled trans-membrane receptors in inner ear tissues of guinea pigs. Hear Res 110: 95-106, 1997

26) Lamprecht J, Plum J: Plasmaspiegel des atrialen natriuretischen Peptids (ANP) nach orlar Glycerol belastung. Laryngol Rhinol Otol 69: 31-34, 1990

27）児玉 章：メニエール病患者の血漿 ANP 濃 度. Equilibrium Res 51: 513-515, 1992

$\left(\begin{array}{l}\text { 原稿到着 : 平成10年 } 9 \text { 月 } 2 \text { 日 } \\ \text { 別刷請求先 : 鈴木幹男 } \\ \text { 个520-2192 滋賀県大津市瀬田月輪町 } \\ \text { 滋賀医科大学耳鼻咽喉科学教室 } \\ \text { E-mail: miki@belle.shiga-med.ac.jp }\end{array}\right)$

